\title{
Prawo pracy wobec rozwoju zatrudnienia cywilnoprawnego
}

\section{Uwagi wstępne}

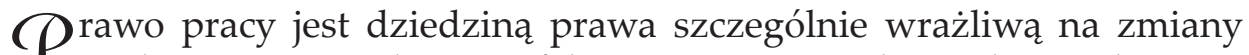
$\int$ społeczne i gospodarcze. Efektem jest jego ciągła ewolucja i dostosowywanie się do nowych warunków i okoliczności. Obserwując toczącą się obecnie dyskusję na temat przyszłości prawa pracy, należy oczekiwać, że proces zasadniczych przemian będzie kontynuowany. W sposób szczególny dotyczy to Polski, która w ostatnim 25-leciu przeszła też zasadniczą ewolucję ustrojową ${ }^{1}$. Jednym z najpoważniejszych problemów, jakie stają obecnie przed prawem pracy jest niewątpliwie kwestia jego zakresu podmiotowego. $Z$ jednej strony przewiduje się schyłek zatrudnienia pracowniczego $\mathrm{w}$ jego dotychczasowej postaci, $\mathrm{z}$ drugiej natomiast dostrzega się potrzebę objęcia ochroną również osób wykonujących pracę na innej podstawie. Powstaje więc pytanie, czy prawo pracy w swojej dotychczasowej formule przestaje być przydatne, czy wręcz przeciwnie - powinno się rozwijać, obejmując swoim zakresem kolejne grupy zatrudnionych. Najistot-

* Dr hab. prof. nadzw., Katedra Prawa Pracy i Polityki Społecznej, Wydział Prawa i Administracji Uniwersytetu Warszawskiego.

${ }^{1} \mathrm{~W}$ dziedzinie prawa pracy nie zdecydowano się jednak na kompleksową reformę, dokonując cząstkowych nowelizacji (M. Seweryński, Problemy rekodyfikacji prawa pracy, [w:] Prawo pracy a wyzwania XXI wieku. Księga Jubileuszowa Profesora Tadeusza Zielińskiego, red. M. Matey-Tyrowicz, L. Nowacki, B. Wagner, Warszawa 2002, s. 320-321). Taka sytuacja jest oceniana jako niewystarczająca z punktu widzenia nowej rzeczywistości ustrojowej i gospodarczej (por. T. Zieliński, Rekodyfikacja prawa pracy - szanse i zagrożenia, „Państwo i Prawo” 2001, nr 2, s. 5). Odpowiedzią na wyzwania współczesności oraz potrzebę stworzenia spójnego i nowoczesnego modelu zatrudniania były m.in. projekty kodeksów pracy przygotowane przez Komisję Kodyfikacyjną Prawa Pracy. Punktem wyjścia było dążenie do osiągnięcia kompromisu między ochroną (która powinna być zachowana) a potrzebami rynku. Zob. m.in. M. Seweryński, Ochrona pracowników przed rozwiazaniem umowy o pracę według projektu kodeksu pracy, [w:] Ochrona trwałości stosunku pracy w społecznej gospodarce rynkowej, red. G. Goździewicz, Warszawa 2010, s. 76-77. 
niejsze wydaje się rozstrzygnięcie dylematu, jak prawo pracy powinno się zachować w odniesieniu do tych osób, które wykonują pracę na rzecz innego podmiotu osobiście i w okolicznościach zbliżonych do zatrudnienia pracowniczego, a które obecnie (o ile są zatrudnione legalnie) zazwyczaj wykonują pracę na podstawie jednej z umów prawa cywilnego. Dwie najważniejsze propozycje to rozszerzenie zakresu podmiotowego prawa pra$\mathrm{cy}^{2}$ oraz budowa prawa zatrudnienia, którego trzon stanowiłoby prawo pracy $^{3}$. Obie koncepcje w pewien sposób uzupełniają się, a ich istotą pozostaje zagwarantowanie adekwatnej ochrony tym, którzy - choć w różnych warunkach - osobiście wykonują pracę ${ }^{4}$. Efektem ma być zapewnienie równowagi w stosunkach społecznych, co należy uznać za podstawowy cel ustawodawstwa w ogóle ${ }^{5}$.

\section{Zróżnicowanie ochrony a prawa podstawowe}

Oceny modelu zatrudnienia należy dokonywać z perspektywy podstawowych wolności i praw ${ }^{6}$, które mają charakter powszechny i których nie można ograniczać do pracowników ${ }^{7}$. Jest oczywiste, że standardy międzynarodowe oraz normy konstytucyjne dotyczące ochrony osób wykonujących pracę wykraczają poza ramy wąsko rozumianego stosunku pracy. Cały system prawny jest skonstruowany w sposób mający chronić godność osoby ludzkiej oraz wolności i prawa, dla których stanowi ona źródło. Jed-

${ }^{2}$ Zob. m.in. W. Sanetra, Uwagi w kwestii zakresu podmiotowego kodeksu pracy, [w:] Prawo pracy a wyzwania XXI wieku..., s. 314 i nast., który postuluje rozszerzenie formuły stosunku pracy (zależność ekonomiczna), a także stworzenie podstawowych gwarancji ochronnych dla osób zatrudnionych na podstawie umów cywilnoprawnych. Nie musi to jednak prowadzić do stworzenia swoistej kodyfikacji, która realizowałaby postulat zupełności. Podobnie M. Seweryński, Problemy rekodyfikacji prawa pracy..., s. 323-324.

3 Taki postulat formułuje M. Gersdorf, Prawo zatrudnienia, Warszawa 2013, s. 32-34. Prawo zatrudnienia miałoby być prawem „dla osób żyjących z pracy rąk, którym należy się z tego tytułu ochrona, a jej zakres i przedmiot wynika ze specyfiki tego zatrudnienia".

${ }^{4} \mathrm{~W}$ rezultacie prawem zatrudnienia byłby zespół norm regulujących osobiste wykonywanie pracy przez osoby fizyczne. Jego istotą jest zapewnienie ochrony adekwatnej do charakteru i warunków wykonywania pracy. Zob. M. Gersdorf, Prawo zatrudnienia..., s. 170.

5 T. Zieliński, Prawo pracy. Zarys systemu, cz. I, Ogólna, Warszawa-Kraków 1986, s. 38. Zob. także E. Durkheim, O podziale pracy społecznej, tłum. K. Wakar, Warszawa 1999, s. 163 oraz s. 263 oraz L. Petrażycki, Teoria prawa i państwa w związku z teoria moralności, opr. J. Lande, Warszawa 1959, s. 257-260.

${ }^{6}$ Wszechstronnej analizy gwarancji konstytucyjnych z perspektywy prawa pracy dokonuje A. Sobczyk, Prawo pracy w świetle Konstytucji RP, t. I i II, Warszawa 2013.

7 Por. A. Sobczyk, Prawo i człowiek pracujacy - między ochrona godności a równości, [w:] Aksjologiczne podstawy prawa pracy i ubezpieczeń społecznych, red. M. Skąpski, K. Ślebzak, Poznań 2014, s. 42-43. 
nocześnie ustrojodawca liczy się ze zróżnicowaniem warunków, w jakich praca jest wykonywana. Znajduje to odzwierciedlenie w samej Konstytucji, której normy w pewnych przypadkach obejmują wszystkich zatrudnionych, w niektórych natomiast tworzą gwarancje jedynie dla pracowników. Oczywiście, konstytucyjne określenie pracownik nie musi być tożsame z definicją znajdującą się w art. 2 k.p., jednoznacznie wskazuje jednak na wewnętrzne zróżnicowanie kategorii osób świadczących pracę. W rezultacie gwarancje konstytucyjne można podzielić na dotyczące wszystkich (w tym osób wykonujących pracę), zatrudnionych sensu largo i wreszcie pracowników - bez przesądzania, w jaki sposób pojęcie to należy rozumieć.

\section{Stosunek pracy a zatrudnienie cywilnoprawne. Stan obecny}

Na gruncie prawa polskiego tradycyjnie przyjmowano podział na stosunek pracy, regulowany przepisami prawa pracy, stosunki służby, regulowane przepisami prawa administracyjnego oraz cywilnoprawne stosunki zatrudnienia ${ }^{8}$. Dla przyszłości rynku pracy kluczowe znaczenie zdaje się mieć wytyczenie granicy między zatrudnieniem pracowniczym a zatrudnieniem cywilnoprawnym ${ }^{9}$. W świetle dzisiejszych założeń stosunek pracy obejmuje osoby zatrudnione $\mathrm{w}$ warunkach podporządkowania (rozumianego coraz bardziej elastycznie), podczas gdy umowy cywilnoprawne to raczej świadczenie usług i kadra kierownicza u części pracodawców. Linia demarkacyjna nie zawsze jest jednak wystarczająco wyraźna, już choćby ze względu na wątpliwości dotyczące tego, jak rozumieć podporządkowanie i kierownictwo pracodawcy ${ }^{10}$. Trzeba przy

${ }^{8}$ Dodać do tego można zatrudnienie penalne oraz ustrojowe (zob. m.in. Z. Kubot, Szczególne formy zatrudnienia i samo zatrudnienia, [w:] Szczególne formy zatrudnienia, red. Z. Kubot, Wrocław 2000, s. 11). Różnice między poszczególnymi reżimami zatrudnienia pozostają dość wyraźne (M. Gersdorf, Prawo zatrudnienia..., s. 18-19). Odrębny problem stanowi zatrudnienie w tzw. szarej strefie.

9 To ostatnie jest uznawane za zjawisko trwałe, które jest uwarunkowane względami gospodarczymi, co nie zmienia faktu, że mogą one stanowić zagrożenie dla prawidłowego rozwoju rynku pracy (M. Seweryński, Problemy rekodyfikacji prawa pracy..., s. 323-324).

10 Ustalenie istnienia podporządkowania w wielu krajach odbywa się przy wykorzystaniu techniki wiązki wskaźników, które określają relację między stronami (A. Supiot, Zatrudnienie pracownicze i zatrudnienie niezależne, [w:] Referaty na VI Europejski Kongres Prawa Pracy i Zabezpieczenia Społecznego, Warszawa 1999, s. 143-146). W Polsce nowelizacja art. 22 $\S 1$ k.p. dokonana w 2002 r. rozdzieliła kierownictwo (podporządkowanie co do sposobu świadczenia) oraz podporządkowanie w zakresie czasu i miejsca pracy. W wyniku tej zmiany pojawiło się pytanie dotyczące sytuacji osób wykonujących pracę w warunkach większej niezależności, gdy chodzi o sposób świadczenia pracy. Odpowiedzią była konstrukcja podporządkowania autonomicznego, która opiera się na założeniu, że dla istnienia tego elementu wystarczający jest fakt wyznaczania pracownikowi zadań, nawet jeśli 
tym pamiętać, że podział na zatrudnienie pracownicze i cywilnoprawne, jakkolwiek znajdujący oparcie normatywne, jest do pewnego stopnia pochodną specyficznych doświadczeń historycznych (obserwowana przed 1989 r. ekspansja stosunku pracy oraz przeciwstawianie mu umów cywilnoprawnych) i nie pozwala w sposób pełny opisać rynku pracy.

O ile zatrudnienie pracownicze i stosunek pracy są przedmiotem kompleksowej regulacji, o tyle zatrudnienie cywilnoprawne stanowi formułę niezwykle zróżnicowaną wewnętrznie. Jakkolwiek praca wykonywana w ramach różnych umów cywilnoprawnych może w praktyce wykazywać pewne podobieństwa, między samymi umowami (w znaczeniu konstrukcji prawnych) występują zasadnicze różnice, w tym również, gdy chodzi o poziom ochrony gwarantowanej zatrudnionym (objęcie przedmiotem zobowiązania efektów pracy, stabilizacja zatrudnienia, wynagrodzenie). Niemniej jednak i w sferze zatrudnienia cywilnoprawnego można zaobserwować kształtowanie się swoistej części ogólnej ${ }^{11}$, którą tworzą m.in. przepisy chroniące godność i inne dobra osobiste zatrudnionych, przepisy chroniące przed dyskryminacją (nierównym traktowaniem) $)^{12}$ oraz zasada wolności pracy. Wreszcie, osoby świadczące pracę na podstawie umów cywilnoprawnych mają prawo do bezpiecznych i higienicznych warunków pracy (art. 304 k.p.), a w pewnym zakresie korzystają także z ochrony swoich roszczeń na wypadek niewypłacalności podmiotu zatrudniającego i są objęte ubezpieczeniami społecznymi. A zatem już dzisiaj status niepracowniczy zbliża się pod pewnymi względami do statusu pracowniczego ${ }^{13}$, choć różnice $\mathrm{w}$ poziomie ochrony są nadal znaczne. Nie należy przy tym oczekiwać, aby Rada Ministrów skorzystała z upoważnienia sformułowanego w art. $303 \S 2$ k.p., które nie odpowiada standardom konstytucyjnym.

Jednocześnie źródłem wątpliwości staje się rozbudowana i w niektórych przypadkach dość sztywna ochrona, którą gwarantuje stosunek pracy. Ostatnie dziesięciolecia to ciągły proces „uelastyczniania” prawa pracy, które to zjawisko dotyka praktycznie wszystkich aspektów stosunku pracy,

korzysta on ze znacznej swobody, gdy chodzi o sposób wykonywania pracy (na ten temat zob. M. Gersdorf, Prawo zatrudnienia..., s. 39-42). Krytycznie na temat koncepcji autonomicznego podporządkowania m.in. T. Duraj, Koncepcja "autonomicznego podporzadkowania" - konflikt wartości pomiędzy autonomia pracownika a jego podporządkowaniem pracodawcy, [w:] Aksjologiczne podstawy prawa pracy i ubezpieczeń społecznych..., s. 107-110.

${ }_{11}$ Szeroko na ten temat M. Gersdorf, Prawo zatrudnienia..., s. 180-181, która formułuje zasady prawa zatrudnienia.

12 Ogólną normę konstytucyjną rozwija w tym zakresie ustawa z 3 grudnia $2010 \mathrm{r}$. o wdrożeniu niektórych przepisów Unii Europejskiej w zakresie równego traktowania. DzU z 2010 r., nr 254, poz. 1700, z późn. zm. Ustawę stosuje się m.in. w zakresie warunków podejmowania i wykonywania działalności gospodarczej lub zawodowej, w tym na podstawie umowy cywilnoprawnej.

${ }^{13}$ Jest to tendencja o charakterze powszechnym. Zob. A. Supiot, Zatrudnienie pracownicze i zatrudnienie niezależne..., s. 146 i nast. 
$\mathrm{w}$ tym trwałości zatrudnienia, czasu pracy czy wynagrodzenia za pracę. W przyszłości należy oczekiwać kontynuacji tej tendencji - stosunek pracy musi ewoluować, aby być formułą zatrudnienia adekwatną do warunków gospodarczych i społecznych ${ }^{14}$. W przeciwnym razie należy się liczyć z nadużywaniem umów cywilnoprawnych czy wręcz zatrudnianiem "na czarno". Kluczowym problemem będzie też wyznaczenie granicy między stosunkiem pracy ${ }^{15}$ a zatrudnieniem niepracowniczym. Możliwe wydaje się zwłaszcza rozwiązanie polegające na rozszerzaniu formuły stosunku pracy (np. oparte na kryterium zależności ekonomicznej), a następnie jego wewnętrzne różnicowanie z uwzględnieniem cech wykonywanej pracy.

Odrębnie należy się odnieść do kwestii ochrony zbiorowej, jaka jest obecnie oferowana zatrudnionym. Z tej korzystają przede wszystkim pracownicy, którym gwarantuje się pełne prawo koalicji i którzy mogą korzystać z efektów dialogu społecznego (są objęci postanowieniami autonomicznych źródeł prawa pracy). Zdecydowana większość zatrudnionych poza stosunkiem pracy znajdowała się w mniej korzystnej sytuacji. Przede wszystkim był to efekt ograniczenia prawa koalicji w art. 2 u.z.z. Rozwiązanie to było krytykowane zarówno z perspektywy podstaw ustrojowych, jak i standardów międzynarodowych ${ }^{16}$. Wątpliwości potwierdził TK w wyroku z 2 czerwca 2015 r., K 1/13, stwierdzając m.in., że art. 2 ust. 1 u.z.z. w zakresie, w jakim ogranicza wolność tworzenia i wstępowania do związków zawodowych osobom wykonującym pracę zarobkową niewymienionym $\mathrm{w}$ tym przepisie, jest niezgodny $\mathrm{z}$ art. 59 ust. $1 \mathrm{w}$ związku $\mathrm{z}$ art. 12 Konstytucji. Osoby zatrudnione na podstawie umów cywilnoprawnych mogą być natomiast objęte postanowieniami układów (art. 239 $\S 2$ k.p.), a w rezultacie chyba również innych porozumień zbiorowych. W kontekście ograniczenia wolności zrzeszania się było to jednak rozwiązanie do pewnego stopnia sztuczne. Niejasny jest przy tym mechanizm działania postanowień układowych, które miałyby wprowadzać standardy zatrudnienia osób wykonujących pracę na podstawie umów prawa cywilnego. Należy oczekiwać, że model zbiorowej reprezentacji osób wykonujących pracę zarobkową, które nie są pracownikami, będzie w najbliższych latach przechodził głęboką ewolucję.

${ }^{14}$ W szczególności ewoluuje ochronny wymiar prawa pracy, dostosowując się do warunków, w jakich prawo pracy funkcjonuje. Por. Z. Salwa, Przemiany prawa pracy początku stulecia a jego funkcja ochronna, [w:] Prawo pracy a wyzwania XXI wieku..., s. 295 i nast.

${ }_{15} \mathrm{Tu}$ na uwagę zasługują zwłaszcza postulaty zastąpienia kryterium podporządkowania kryterium zależności ekonomicznej (m.in. W. Sanetra, Uwagi w kwestii zakresu podmiotowego kodeksu pracy..., s. 314-315).

16 Zob. m.in. M. Seweryński, Problemy legislacyjne zbiorowego prawa pracy, [w:] Prawo pracy RP w obliczu przemian, red. M. Matey-Tyrowicz, T. Zieliński, Warszawa 2006, s. 388389 oraz Z. Hajn, Prawo zrzeszania się w zwiąkach zawodowych - prawo pracowników czy prawo ludzi pracy, [w:] Zbiorowe prawo pracy w XXI wieku, red. A. Wypych-Żywicka, M. Tomaszewska, J. Stelina, Gdańsk 2010, s. 175 i nast. 


\section{Przesłanki zróżnicowania statusu prawnego zatrudnionych}

Dla rozwoju prawa pracy, a nawet szeroko rozumianego prawa zatrudnienia, kluczowe jest pytanie, czy w dalszym ciągu należy korzystać z kryteriów, które tradycyjnie wyznaczały granicę między zatrudnieniem pracowniczym a niepracowniczym. W szczególności dotyczy to kryterium podporządkowania. Nawet w przypadku krytycznego podejścia do kryteriów wyodrębnienia i zakresu podmiotowego prawa pracy trudno nie dostrzec różnic istniejących między różnymi grupami osób wykonujących pracę. Inna jest sytuacja zatrudnionego na stałe, który swoją karierę zawodową wiąże z jednym podmiotem i świadczy pracę $\mathrm{w}$ warunkach podporządkowania, inne natomiast jest położenie osoby faktycznie samozatrudnionej, która wykonuje pracę osobiście, ale na rzecz wielu kontrahentów, decydując przy tym o stronie organizacyjnej i sposobie realizacji świadczenia. Warunki wykonywania pracy i charakter więzi istniejącej między kontrahentami to okoliczności, które muszą determinować kształt potencjalnej ochrony. Gdy staramy się najogólniej określić granice między poszczególnymi kategoriami zatrudnionych, kluczowe wydają się dwa kryteria: zależność ekonomiczna oraz podporządkowanie osoby świadczącej pracę. Zależność ekonomiczna podkreśla dominację odbiorcy usługi i znaczenie stosunku prawnego z punktu widzenia dochodów zatrudnionego. Z kolei podporządkowanie, kwestionowane ostatnio jako przydatne kryterium różnicowania ${ }^{17}$, eksponuje fakt organizowania procesu pracy przez podmiot, który ze świadczenia korzysta. Natężenie wspomnianych cech zatrudnienia $\mathrm{w}$ poszczególnych stosunkach prawnych powinno w rezultacie determinować zastosowane mechanizmy ochronne.

Analizę można rozpocząć od sytuacji skrajnych - zależności w obu postaciach oraz braku zależności. Pierwszy przypadek to łączne występowanie zależności ekonomicznej i organizacyjnej. Jest to sytuacja, która zasadniczo odpowiada obecnej konstrukcji stosunku pracy. Pracownik jest nie tylko zależny od pracodawcy w znaczeniu ekonomicznym, lecz również wykonuje pracę $\mathrm{w}$ warunkach zorganizowanych przez podmiot zatrudniający. $Z$ reguły są więc możliwe do zastosowania wszystkie mechanizmy ochronne wypracowane na gruncie prawa pracy. Drugi przypadek skrajny to osoby, które można określićjako niezależne w wykonywaniu pracy. Mają one licznych kontrahentów (żaden z nich nie może być uznany za głównego klienta) i samodzielnie organizują proces pracy. W ich przypadku konstrukcje ochronne, które potencjalnie mogłyby zostać zastosowane, ulegają

17 A. Sobczyk, Prawo i człowiek pracujący - między ochrona godności a równości..., s. 42, 45 i 58. 
znacznemu ograniczeniu. Dotyczy to zwłaszcza sfery organizacji procesu pracy (czas pracy, przerwy w wykonywaniu zadań). Znacznie trudniej byłoby również zastosować jednolitą konstrukcję ochronną w zakresie wynagrodzenia. W grę wchodziłoby określenie minimalnych stawek godzinowych lub podobnych (które teoretycznie mogłyby być wspólne zarówno dla pracowników, jak i samozatrudnionych), jednak taki mechanizm oznaczałby zasadniczą ingerencję w sferę swobody umów i reglamentowanie całej gospodarki. Możliwe, a nawet konieczne, jest natomiast stosowanie takich standardów ochronnych, jak ochrona godności i innych dóbr osobistych zatrudnionego, ochrona przed dyskryminacją, a także ochrona życia i zdrowia w procesie pracy (bhp), zwłaszcza jeżeli praca jest wykonywana $\mathrm{w}$ miejscu zarządzanym przez inny podmiot.

Gdy chodzi o sytuacje pośrednie szczególne znaczenie ma przypadek, gdy występuje zależność ekonomiczna, zależność organizacyjna jest natomiast na tyle słaba, że nie może być uznana za podporządkowanie sensu stricto. W tych przypadkach poza ochroną przysługującą wszystkim zatrudnionym należy rozważyć stosowanie jeszcze innych gwarancji, które można uzasadnić warunkami wykonywania pracy. Po pierwsze, w takiej sytuacji możliwa jest pewna stabilizacja zatrudnienia. Konstrukcja ta jest znana prawu cywilnemu (umowa agencyjna), a zatem nie powinna być odrzucana a priori. Trwałość umowy, w przypadku prac o charakterze stałym, odzwierciedlałaby w gruncie rzeczy istotną cechę danego typu zatrudnienia, stabilizując przy tym sytuację osoby zależnej ekonomicznie. Po drugie, można też rozważać zastosowanie pewnych konstrukcji ochronnych ze sfery organizacyjnej. Dotyczy to np. urlopów wypoczynkowych (o ile zatrudnienie ma charakter trwały), trudniejsze byłoby już natomiast zagwarantowanie ochrony przez ustanowienie norm czasu pracy (korzystający z usługi nie ma dostatecznego wpływu na przebieg procesu pracy).

Podsumowując należy stwierdzić, że tworząc odpowiednie formy zabezpieczenia osób pracujących, trzeba odwoływać się do istoty stosunku prawnego, jaki wiąże je z odbiorcą świadczenia. Proste wskazanie na rodzaj zawartej umowy, np. umowę o dzieło czy umowę na warunkach zlecenia nie jest wystarczające. Przy takich założeniach i biorąc pod uwagę podstawowe cechy relacji istniejących między zatrudniającymi a osobami świadczącymi pracę, można wyróżnić trzy główne grupy zatrudnionych: zależnych ekonomicznie i organizacyjnie - pracownicy (employees), zależnych ekonomicznie (economically dependant workers) oraz niezależnych - samozatrudnieni (economically independant workers, self-employed), którzy jednak wykonują pracę osobiście, nie zatrudniając innych osób ${ }^{18}$. Grupę

${ }_{18}$ Krytycznie na temat tego podziału zob. M. Gersdorf, Prawo zatrudnienia..., s. 28-29. Do kategorii zależnych ekonomicznie odwołuje się natomiast A. Musiała, Zatrudnienie niepracownicze, Warszawa 2011 (m.in. s. 69). 
ekonomicznie zależnych można następnie różnicować przy wykorzystaniu kryterium trwałości zatrudnienia. Charakter pracy i więzi prawnej z kontrahentem $\mathrm{w}$ ramach każdej $\mathrm{z}$ tych grup będzie determinować zakres ochrony - nie ze względu na osobę, która pracę świadczy, ale ze względu na okoliczności towarzyszące procesowi pracy. Powyższe rozważania uzasadniają też wniosek o zasadności wyodrębnienia prawa pracy, które jakkolwiek musi ewoluować, to jednak pozostaje formą zatrudnienia odpowiadającą warunkom wykonywania pracy przez znaczną część pracujących. Jednocześnie nie można wykluczyć, że w przyszłości podstawową tendencją stanie się ekspansja prawa pracy i obejmowanie jego zakresem również innych grup zatrudnionych, w tym zwłaszcza ekonomicznie zależnych. Prawdopodobnie będzie to prowadzić do osłabiania ochrony i jej wewnętrznego różnicowania, być może również na podstawie kryterium podporządkowania $\mathrm{w}$ tradycyjnym znaczeniu. Jednocześnie postuluje się tworzenie gwarancji, które zapewnią osobom pracującym ochronę nie tylko $\mathrm{w}$ ramach poszczególnych umów, lecz w odniesieniu do ich pozycji rynkowej i kariery zawodowej ${ }^{19}$.

\section{Zatrudnienie niepracownicze w projektach kodeksów pracy}

W tym kontekście należy zwrócić uwagę na propozycję Komisji Kodyfikacyjnej, która w projekcie kodeksu pracy przewidziała wprowadzenie kategorii zatrudnienia niepracowniczego, w tym zatrudnienia niepracowniczego na podstawie umowy. Wyróżnić tu można dwa poziomy ochrony. Po pierwsze, wszyscy pozostający w zatrudnieniu niepracowniczym (wykonujący pracę osobiście) byliby objęci przepisami statuującymi ochronę w zakresie życia i zdrowia (art. 476 projektu) ${ }^{20}$. Nie można przy tym zapominać, że ta grupa zatrudnionych została również włączona do systemu ubezpieczeń społecznych. Po drugie, wyższy standard ochrony miałby dotyczyć osób w zatrudnieniu niepracowniczym na podstawie umowy (art. 462), które wykonują pracę w określonych warunkach. Tej kategorii zatrudnionych projektodawca planował przyznać pewne uprawnienia zbliżające ich (choć w ograniczonym zakresie) do sytuacji pracowników. Trzon przepisów ochronnych stanowiłyby nadal gwarancje dotyczące pracowników w ścisłym znaczeniu.

19 A. Supiot, Zatrudnienie pracownicze i zatrudnienie niezależne..., s. 172. Celowi temu może sprzyjać zbliżanie się statusów pracowniczego i niepracowniczego.

${ }^{20}$ Odpowiada to postulatom formułowanym przez W. Sanetrę, Uwagi w kwestii zakresu podmiotowego kodeksu pracy..., s. 316-317. 
Z tej perspektywy interesujące są zwłaszcza kryteria, które miały pozwolić na wyodrębnienie grupy zatrudnionych (niepracowniczo) na podstawie umowy. Zgodnie $\mathrm{z}$ art. $462 \S 1$ projektu chodziłoby o osoby zatrudnione na innej podstawie niż umowa o pracę, które wykonują pracę o charakterze ciągłym lub powtarzającym się ${ }^{21}$, osobiście ${ }^{22}$ i na rzecz jednego zatrudniającego, za wynagrodzeniem przekraczającym połowę minimalnego wynagrodzenia za pracę. Ochroną miałyby być również objęte osoby związane z większą liczbą kontrahentów, jednak wykonujące pracę na rzecz zatrudniającego, od którego uzyskują większą część wynagrodzenia, jeżeli przekracza ono połowę minimalnego wynagrodzenia za pracę (art. $462 \S 2$ k.p.). Jest to podejście zrozumiałe, gdyż fakt występowania ubocznych relacji prawnych, które nie mają zasadniczego wpływu na sytuację zatrudnionego, nie powinien pozbawiać go ochrony w stosunku prawnym z głównym kontrahentem. Jednocześnie tak skonstruowana ochrona nie obejmowałaby relacji incydentalnych.

Projektodawca odwołuje się więc do swoistego zespołu cech charakteryzujących relację, której trzon tworzą fakt osobistego świadczenia pracy, więź ekonomiczna oraz trwałości zobowiązania ${ }^{23}$. Zatrudniającym jest podmiot występujący $\mathrm{w}$ roli jedynego lub głównego kontrahenta, z którym relacja jest szczególnie intensywna. Warto zwłaszcza podkreślić fakt łącznego potraktowania więzi (zależności) ekonomicznej i trwałości zatrudnienia. Jest to $\mathrm{w}$ pełni zrozumiałe, gdyż odwołanie się do samego kryterium ekonomicznego z pominięciem charakteru zatrudnienia byłoby do pewnego stopnia bezużyteczne ${ }^{24}$. Sytuacja grupy zatrudnionych wykonujących pracę $\mathrm{w}$ opisanych warunkach $\mathrm{w}$ największym stopniu zbliża się do sytuacji pracowników, choć brak jest pozostałych cech typowych dla stosunku pracy, w tym zwłaszcza elementu podporządkowania.

${ }^{21}$ Ciągłość i powtarzalność nie tylko wskazują na trwały charakter zatrudnienia, lecz również eksponują ograniczone możliwości zatrudnionego, gdy chodzi o uzyskiwanie dochodów z innych źródeł. Jako możliwe kryteria ustalenia trwałości zobowiązania wskazuje się fakt istnienia więzi o charakterze bezterminowym lub trwającym co najmniej sześć miesięcy (M. Gersdorf, Prawo zatrudnienia..., s. 172). Wydaje się, że sam czas trwania zobowiązania nie jest jeszcze wystarczającym kryterium. Niektóre mechanizmy ochronne trudno byłoby zastosować, jeżeli do świadczenia dochodzi rzadko. Dlatego warto również zwrócić uwagę na intensywność procesu pracy.

${ }^{22}$ Osobistego charakteru pracy nie wyłączałoby korzystanie przez osobę zatrudnioną z pomocy członków rodziny pozostających z nią we wspólnym gospodarstwie domowym (art. $462 \S 3$ k.p.).

${ }^{23}$ Por. uzasadnienie projektu kodeksu pracy, s. 44.

${ }_{24}$ Zastosowanie pewnych instrumentów ochronnych, które nawiązują do prawa pracy, nie jest możliwe w razie świadczenia jednorazowego lub krótkotrwałego, nawet jeśli świadczący usługę miałby uzyskać stosunkowo wysokie wynagrodzenie (ochrona trwałości zatrudnienia, urlop wypoczynkowy). 
Konstruując ochronę ekonomicznie zależnych, Komisja Kodyfikacyjna zastosowała mieszaną metodę regulacji. Przede wszystkim nie zdecydowano się na proste rozszerzenie zakresu podmiotowego kodeksu, uznając, że położenie zatrudnionych niebędących pracownikami nie uzasadnia takiego rozwiązania. Projekt odsyła do wybranych przepisów pracowniczych, a jednocześnie tworzy też autonomiczne konstrukcje ochronne, które nawiązują do części pracowniczej, ale jednocześnie są dostosowane do specyfiki zatrudnienia na innych podstawach prawnych. I tak, dopuszczono możliwość objęcia nie-pracowników autonomicznymi źródłami prawa pracy oraz przewidziano stosowanie mechanizmu uprzywilejowania (art. 464 projektu). Projektodawca zakłada pewną stabilizację zatrudnienia, proponując minimalne okresy wypowiedzenia i akceptując rozwiązanie bez wypowiedzenia jedynie w szczególnych przypadkach (art. 466-468 projektu) ${ }^{25}$. Oczywista jest konieczność stosowania przepisów dotyczących równego traktowania w zatrudnieniu (art. 469 projektu). Co więcej, zatrudniający byłby obowiązany udzielać zwolnień od pracy (w uzasadnionych przypadkach) oraz urlopów wypoczynkowych i urlopów macierzyńskich (w wymiarze 16 tygodni), z tym że zatrudnieni nie zachowywaliby prawa do wynagrodzenia (art. 471 i 472 projektu). Wreszcie, okres takiego zatrudnienia (pod warunkiem uzyskiwania wynagrodzenia na określonym poziomie) wliczałby się do stażu pracy (art. 473 projek$\mathrm{tu}^{26}$. Zasadniczy kształt propozycji zasługuje na aprobatę. Jest to próba stworzenia kompleksowej ochrony, która zagwarantuje realizację praw podstawowych, a przy tym będzie dostosowana do warunków wykonywania pracy. Ważne jest również, że projekt nie narusza istoty stosunków prawnych, na które ochrona miałaby się nałożyć. Jest to kluczowe z punktu widzenia systemu prawnego jako całości oraz podstaw ustrojowych ${ }^{27}$ (społeczna gospodarka rynkowa, ochrona własności, swoboda prowadzenia działalności gospodarczej). Nie oznacza to oczywiście, że proponowane rozwiązania nie budzą wątpliwości. Pojawiają się one, gdy chodzi zarówno o zakres ${ }^{28}$, jak i kształt ${ }^{29}$ przyznanej ochrony. Niemniej jednak przedstawiona propozycja może stanowić punkt wyjścia dalszej dyskusji na temat przyszłej koncepcji prawa zatrudnienia.

${ }_{25}$ Szerzej na ten temat M. Seweryński, Ochrona pracowników przed rozwiąaniem umowy o pracę...

${ }^{26}$ Obecne rozwiązania są w tym zakresie wysoce niezadowalające. Zob. więcej P. Walorska, Staż pracy, Warszawa 2014, s. 255 i nast. Dodatkowe warunki do takiego zaliczenia formułuje W. Sanetra, Uwagi w kwestii zakresu podmiotowego kodeksu pracy..., s. 315.

27 Uzasadnienie projektu kodeksu pracy, s. 44.

28 Przykładem może być stosowanie przepisów o ochronie wynagrodzenia - na wzór ochrony wynagrodzenia za pracę (por. M. Gersdorf, Prawo zatrudnienia..., s. 190).

${ }_{29}$ Tu można się zastanawiać, czy wystarczające są np. gwarancje w zakresie trwałości zatrudnienia. Dość krótkie okresy wypowiedzenia dotyczyłyby również osób mających za sobą wieloletnią współpracę z danym kontrahentem. 
Proponowane rozwiązania w pewnym stopniu dotykają też kwestii zbiorowej reprezentacji interesów osób zatrudnionych ${ }^{30}$. Ustawodawca wyraźnie przewiduje możliwość objęcia ich zakresem stosowania układów i innych porozumień zbiorowych. Pojawia się jednak pytanie, dlaczego takiej możliwości mieliby być pozbawieni ci, którzy również utrzymują się ze swojej pracy, nie są jednak uzależnieni od jednego kontrahenta. Szczególnie w kontekście rokowań ogólnokrajowych, branżowych czy regionalnych ich interesy też mogłyby być w pewien sposób chronione. Punktem wyjścia pozostaje jednak zakres podmiotowy wolności koalicji. Nie ulega kwestii, że koniecznością jest rezygnacja z obecnych ograniczeń, tak aby z ochrony zbiorowej mogli korzystać również ludzie pracy niebędący pracownikami.

Zastanawiając się nad kształtem nowych rozwiązań, na pierwszym miejscu należałoby postawić autonomię partnerów społecznych. Uznając, że istotą działania związków zawodowych jest reprezentowanie i ochrona praw oraz interesów ludzi pracy, im samym należałoby pozostawić określenie grupy osób, którą miałyby reprezentować ${ }^{31}$. Będzie ona determinowana przez charakter i zakres działania danej organizacji, jednak z zastrzeżeniem istotnego ograniczenia, jakim jest fakt osobistego zaangażowania $\mathrm{w}$ proces pracy. Dzięki takiemu podejściu istniałaby możliwość dostosowania prowadzonych negocjacji zbiorowych do okoliczności, w jakich się one odbywają. W niektórych przypadkach związki zawodowe mogłyby się ograniczyć do reprezentowania tylko pracowników, podczas gdy w innych działałyby również na rzecz pozostałych grup

${ }^{30}$ Problem ten jest $\mathrm{w}$ gruncie rzeczy dużo głębszy wobec kryzysu tradycyjnej reprezentacji opartej na związkach zawodowych (M. Gersdorf, Prawo zatrudnienia..., s. 23). Trudno byłoby jednak całkowicie rezygnować z koncepcji reprezentacji zbiorowej, która stanowi przecież jeden z podstawowych mechanizmów ochronnych (L. Florek, Ochrona praw i interesów pracownika, Warszawa 1990, s. 17; Z. Hajn, Zbiorowe prawo pracy. Zarys systemu, Warszawa 2013, s. 31), nawet jeśli praktyka dialogu społecznego nie jest w tym zakresie satysfakcjonująca (M. Seweryński, Dylematy prawnej ochrony pracy, [w:] Z zagadnień prawa pracy i prawa socjalnego. Ksiegga jubileuszowa Profesora Herberta Szurgacza, red. Z. Kubot, T. Kuczyński, Warszawa 2011, s. 220-221). Odpowiedzią może być rozwój innych form reprezentacji interesów pracowniczych, $\mathrm{w}$ tym zwłaszcza przedstawicielstw wybieranych. W tym przypadku pojawia się jednak kryterium dość ścisłego związku reprezentowanych z konkretnym zakładem pracy. Kryterium tego nie spełnia znaczna część zatrudnionych, którzy nie są pracownikami.

${ }_{31}$ M. Seweryński, Uwagi o przyszłości układów zbiorowych pracy, [w:] Układy zbiorowe pracy. W stulecie urodzin Profesora Wacława Szuberta, red. Z. Góral, Warszawa 2013, s. 87, eksponuje ogólną tendencję, jaką jest zwiększanie się autonomii jednostek i wspólnot, a co za tym idzie decentralizacja procesu tworzenia prawa. Za szerokim ujęciem prawa koalicji opowiada się m.in. A. Sobczyk, Prawo i człowiek pracujacy - między ochrona godności a równości..., s. 58. Jednak i tu charakter zatrudnienia może wpływać na zakres uprawnień. 
zatrudnionych ${ }^{32}$. W rezultacie dialog społeczny uzyskiwałby konieczną przestrzeń, a partnerzy społeczni rzeczywistą możliwość kształtowania warunków, w jakich praca jest wykonywana. Nie można wykluczać, że w niektórych sytuacjach negocjacje mogłyby dotyczyć nawet tych pracujących, którzy nie odpowiadają standardom zależności ekonomicznej, pozostając w znacznym oddaleniu od typowego zatrudnienia pracowniczego. $W$ ich przypadku możliwe są również alternatywne sposoby reprezentacji, np. w formie różnego rodzaju izb zawodowych. W świetle przedstawionych uwag należy pozytywnie ocenić koncepcję Komisji Kodyfikacyjnej, która zaproponowała, aby prawo tworzenia i wstępowania do związków zawodowych przysługiwało nie tylko pracownikom, lecz również osobom wykonującym pracę zarobkowa, które nie są pracodawcami (art. $15 \S 1$ projektu zbiorowego kodeksu pracy).

\section{Prawo zatrudnienia a skuteczność prawa}

Dzisiejsza dyskusja na temat przyszłego kształtu prawa zatrudnienia jest silnie uwarunkowana aktualną sytuacją na rynku pracy. Postulaty rozszerzenia ochrony stanowią odpowiedź na rosnącą liczbę osób zatrudnianych $\mathrm{w}$ ramach umów cywilnoprawnych. W pierwszej kolejności należałoby jednak odpowiedzieć na pytanie, czy potencjalni beneficjenci rozszerzenia są rzeczywiście osobami niemającymi statusu pracowniczego, czy też zawierane z nimi umowy cywilnoprawne ukrywają faktyczne zatrudnienie pracownicze (tak jak jest ono obecnie rozumiane). Jakakolwiek precyzyjna odpowiedź na pytanie o skalę sztucznego zatrudnienia cywilnoprawnego jest niemożliwa, nie ulega jednak wątpliwości, że zjawisko to dotyczy znacznej części osób pracujących poza stosunkiem pracy. Taki stan rzeczy stanowi konsekwencję małej efektywności obecnych rozwiązań ochronnych (brak domniemania stosunku pracy ${ }^{33}$, powództwo o ustalenie istnienia stosunku pracy). Dlatego w pierwszej kolejności należałoby stworzyć skuteczniejsze mechanizmy weryfikacji podstaw zatrudnienia. Pozwoli to realnie określić grupę zatrudnionych nie-pracowników. Kontrargumentem nie może być natomiast teza, w myśl której obecna sytuacja to efekt nadmiernych obciążeń wynikających z prawa

${ }^{32} \mathrm{Na}$ temat rozszerzenia się zakresu negocjacji zbiorowych zob. A. Supiot, Zatrudnienie pracownicze i zatrudnienie niezależne..., s. 170. Zob. także M. Seweryński, Problemy legislacyjne zbiorowego prawa pracy..., s. 389. Z drugiej strony, w niektórych krajach ten swobodny rozwój dialogu społecznego jest ograniczany przez bardziej rygorystyczne podejście do zakresu podmiotowego rokowań. Alternatywą mogą się stać modyfikacje definicji pracownika.

${ }^{33}$ Na ten temat m.in. K. Rączka, Czy domniemanie stosunku pracy?, „Przegląd Ubezpieczeń Społecznych i Gospodarczych" 1997, nr 2. 
pracy. Otwarte posługiwanie się taką retoryką oznaczałoby, że ze względów pragmatycznych akceptuje się zawieranie umów cywilnoprawnych w warunkach stosunku pracy. Punktem wyjścia powinna być skuteczna egzekucja prawa pracy. Z drugiej strony prawo to musi odpowiadać potrzebom społeczeństwa i gospodarki. Dlatego jednocześnie możliwa, a nawet konieczna, jest dyskusja na temat przyszłego kształtu stosunku pracy i jego wewnętrznego zróżnicowania, tak aby mógł się stać adekwatną podstawą zatrudnienia w społecznej gospodarce rynkowej. Dyskusja ta powinna dotyczyć zarówno samej kwalifikacji stosunków prawnych jako stosunków pracy (sposób określenia kryteriów delimitacji), jak też zakresu obciążeń pracodawcy.

\section{Zakończenie}

Przemiany dokonujące się na rynku pracy wymuszają reakcję ustawodawcy. Trudno byłoby abstrahować od rosnącej liczby osób, które świadczą pracę osobiście, lecz nie korzystają z ochrony oferowanej przez prawo pracy - co budzi wątpliwości już choćby z perspektywy realizacji wolności i praw podstawowych. Potrzebna jest nowa koncepcja ochrony, ale ochrony spójnej i dostosowanej do warunków wykonywanej pracy. Przede wszystkim ustawodawstwo nie powinno petryfikować stanów niezgodnych z prawem. Nie powinno się tworzyć ochrony, która a priori zakłada obchodzenie przepisów o zatrudnieniu pracowniczym. Nie oznacza to oczywiście, że osoby zatrudnione w ramach rzekomych umów cywilnoprawnych mają być pozbawione ochrony, którą gwarantuje szeroko rozumiane prawo zatrudnienia. Istotne jest natomiast, aby w pierwszej kolejności zwiększyć skuteczność prawa (wyeliminowanie fałszywych umów cywilnoprawnych i samozatrudnienia).

Ochrona zatrudnionych powinna zależeć nie tyle od rodzaju zawartej umowy, ile od charakteru wykonywanej pracy. Byłby to swoisty parasol ochronny, który nie niweczyłby istoty poszczególnych umów. O ile warunkiem sine qua non zastosowania konstrukcji ochronnych jest fakt osobistego wykonywania pracy, o tyle wyższe standardy ochronne powinny być gwarantowane $\mathrm{w}$ przypadku osób zależnych od zatrudniającego (w pewnym uproszczeniu można tu mówić o zależności ekonomicznej). Pełne wykorzystanie instrumentów ochronnych jest natomiast możliwe w przypadku tych zatrudnionych, którzy wykonują pracę nie tylko w warunkach zależności ekonomicznej, lecz również podporządkowania organizacyjnego. W tym kierunku zmierza projekt kodeksu pracy przygotowany przez Komisję Kodyfikacyjna, tworzący swoistą część ogólną prawa zatrudnienia - $\mathrm{w}$ takim zakresie, $\mathrm{w}$ jakim nie koliduje $\mathrm{z}$ innymi zasadami 
ustrojowymi. Nie wyklucza to oczywiście techniki przepisów szczególnych, które mogłyby znaleźć zastosowanie w przypadku wybranych grup zatrudnionych. Odrębnym problemem pozostaje kształt prawa pracy w ścisłym znaczeniu. Ono również musi ewoluować dostosowując się do warunków, w jakich praca jest wykonywana. Nieuchronne wydają się jego dalsze uelastycznienie oraz wewnętrzne zróżnicowanie, które pozwoli objąć zakresem jego stosowania różne kategorie zatrudnionych.

\section{Bibliografia}

Duraj T., Koncepcja „autonomicznego podporzadkowania” - konflikt wartości pomiędzy autonomia pracownika a jego podporzadkowaniem pracodawcy, [w:] Aksjologiczne podstawy prawa pracy i ubezpieczeń społecznych, red. M. Skąpski, K. Ślebzak, Poznań 2014.

Durkheim E., O podziale pracy społecznej, tłum. K. Wakar, Warszawa 1999.

Florek L., Ochrona praw i interesów pracownika, Warszawa 1990.

Gersdorf M., Prawo zatrudnienia, Warszawa 2013.

Hajn Z., Prawo zrzeszania się w zwiąkach zawodowych - prawo pracowników czy prawo ludzi pracy, [w:] Zbiorowe prawo pracy w XXI wieku, red. A. Wypych-Żywicka, M. Tomaszewska, J. Stelina, Gdańsk 2010.

Hajn Z., Zbiorowe prawo pracy. Zarys systemu, Warszawa 2013.

Kubot Z., Szczególne formy zatrudnienia i samo zatrudnienia, [w:] Szczególne formy zatrudnienia, red. Z. Kubot, Wrocław 2000.

Musiała A., Zatrudnienie niepracownicze, Warszawa 2011.

Petrażycki L., Teoria prawa i państwa w zwiazku z teoria moralności, opr. J. Lande, Warszawa 1959.

Rączka K., Czy domniemanie stosunku pracy?, „Przegląd Ubezpieczeń Społecznych i Gospodarczych" 1997, nr 2.

Salwa Z., Przemiany prawa pracy początku stulecia a jego funkcja ochronna, [w:] Prawo pracy a wyzwania XXI wieku. Księga Jubileuszowa Profesora Tadeusza Zielińskiego, red. M. Matey-Tyrowicz, L. Nawacki, B. Wagner, Warszawa 2002.

Sanetra W., Uwagi w kwestii zakresu podmiotowego kodeksu pracy, [w:] Prawo pracy a wyzwania XXI wieku. Księga Jubileuszowa Profesora Tadeusza Zielińskiego, red. M. Matey-Tyrowicz, L. Nowacki, B. Wagner, Warszawa 2002.

Seweryński M., Dylematy prawnej ochrony pracy, [w:] Z zagadnień prawa pracy i prawa socjalnego. Księa jubileuszowa Profesora Herberta Szurgacza, red. Z. Kubot, T. Kuczyński, Warszawa 2011.

Seweryński M., Ochrona pracowników przed rozwiązaniem umowy o pracę według projektu kodeksu pracy, [w:] Ochrona trwałości stosunku pracy w społecznej gospodarce rynkowej, red. G. Goździewicz, Warszawa 2010.

Seweryński M., Problemy legislacyjne zbiorowego prawa pracy, [w:] Prawo pracy RP w obliczu przemian, red. M. Matey-Tyrowicz, T. Zieliński, Warszawa 2006.

Seweryński M., Problemy rekodyfikacji prawa pracy, [w:] Prawo pracy a wyzwania XXI wieku. Księga Jubileuszowa Profesora Tadeusza Zielińskiego, red. M. Matey-Tyrowicz, L. Nowacki, B. Wagner, Warszawa 2002.

Seweryński M., Uwagi o przyszłości układów zbiorowych pracy, [w:] Układy zbiorowe pracy. W stulecie urodzin Profesora Wacława Szuberta, red. Z. Góral, Warszawa 2013. 
Sobczyk A., Prawo i człowiek pracujacy - między ochrona godności a równości, [w:] Aksjologiczne podstawy prawa pracy i ubezpieczeń społecznych, red. M. Skąpski, K. Ślebzak, Poznań 2014.

Sobczyk A., Prawo pracy w świetle Konstytucji RP, t. I i II, Warszawa 2013.

Supiot, A., Zatrudnienie pracownicze i zatrudnienie niezależne, [w:] Referaty na VI Europejski Kongres Prawa Pracy i Zabezpieczenia Społecznego, Warszawa 1999.

Walorska P., Staż pracy, Warszawa 2014.

Zieliński T., Prawo pracy. Zarys systemu, cz. I, Ogólna, Warszawa-Kraków 1986.

Zieliński T., Rekodyfikacja prawa pracy - szanse i zagrożenia, „Państwo i Prawo” 2001, nr 2.

\title{
Labour Law and the Development of Civil Law Employment
}

\begin{abstract}
Summary
Over the recent years the labour law has undergone significant changes. One of the most important problems is its personal scope. The main question concerns the protection of workers engaged outside the employment relationship. First of all, the legislation must safeguard the fundamental rights arising from international and constitutional standards. At the moment the Polish labour law distinguishes between employment and civil law contracts. Employees are protected to the largest extent. The protection of workers is limited to anti-discriminatory measures, health and safety regulations and the social insurance. The protection offered by collective labour law is not sufficient either. In the future the legislation must adjust the protective measures to the character and nature of work. Consequently the law may protect in a different manner dependant employees, economically-dependant workers and self-employed. Also the system of industrial relationships must be reconstructed. Finally, all working people must be protected in an adequate way. It is necessary to achieve the equilibrium between management and labour.
\end{abstract}

